\title{
A função materna do trabalho institucional: análise de intervenções psicanalíticas em casos de autismo.
}

\section{Kauê da Costa Alves*; Kelly Cristina Brandão da Silva (orientador)}

\section{Resumo}

O presente trabalho propõe-se a discutir os efeitos do trabalho instituicional em um Programa de Intervenção Precoce para crianças com sintomas autísticos. A priori, é apresentado um panorama sobre a função materna como primordial para a constituição psiquica, de acordo com o referencial teórico psicanálitico. A posteriori, dialoga-se a respeito da importância da função materna no trabalho institucional e suas reverberações nos casos atendidos no Programa.

\section{Palavras-chave: Instituição, Psicanálise, Autismo, Função Materna.}

\section{Introdução}

Para a psicanálise, para que um sujeito emerja em um plano simbólico, é necessário que anteriormente ele seja falado por um outro, agente da função materna. Esta fala, marcada no plano da linguagem, imprimirá marcas e significados que, em um tempo posterior, permitirá que o sujeito saia da posição daquele que é falado, para que surja em um campo de enunciação. Em quadros de sujeitos com sinais autísticos, esta equação fundamental ao psiquismo sofre atravessamentos diversos, gerando uma série de impasses no laço cuidador-bebê. Para o pequeno infans, a alienação primordial ao "mundo dos significantes", como destaca Lacan (1988), Ihe é penosa. Enquanto para 0 cuidador, suas possibilidades maternantes são, frequentemente, terrivelmente afetadas devido às incisivas feridas narcísicas causadas por um bebê que não corresponde. $O$ trabalho institucional orientado pela psicanálise, nestes casos, tem como premissa sustentar esta função tão importante, a fim de assegurar aspectos constitucionais primordiais ao bebê. Diante disso, o presente trabalho tem como proposta apresentar e discutir a função materna assumida pela instituição em atendimentos sustentados a partir da psicanálise, em um Programa de Intervenção Precoce.

\section{Metodologia}

Estudo qualitativo, retrospectivo e longitudinal, a partir de uma amostra de conveniência da pesquisa "Sinais de risco e sofrimento psíquico na primeira infância: identificação e estratégicas de intervenção", aprovada pelo Comitê de Ética em Pesquisa da FCM/UNICAMP, com o parecer 1.846.495. A amostra constitui-se de duas crianças, de 3 anos e 3 meses e 3 anos e 1 mês, atendidas no Programa de Treinamento em Serviço "Intervenção Precoce Em Crianças de 0 a 3 anos", oferecido no Centro de Estudos e Pesquisas em Reabilitação "Prof. Dr. Gabriel O.S. Porto" (CEPRE/FCM/UNICAMP), no período de 1 ano e 8 meses, acompanhadas por suas mães.

\section{Resultados e Discussão}

Igor e Serafim (nomes fictícios) possuem como características similares, o alheamento ao contato com outro; o brincar e a manipulação de objetos de forma pouco inovadora e repetitiva; além da dificuldade materna em lidar com suas idiossincrasias. Igor tem como característica peculiar, a deambulação, enquanto no caso de Serafim, a indiferença e apatia são marcas contundentes. A música e o canto são estratégias terapêuticas utilizadas para circunscrever bordas nos atendimentos, atribuindo significados ao vazio característico de seus movimentos. Igor passa, aos poucos, a ceder os movimentos antes desconexos, como esbarrões que costumava dar, tanto no corpo da psicóloga quanto nos objetos, a movimentos regidos por certa temporalidade e intencionalidade. Serafim, que antes demonstrava indiferença ao contato com o outro, passa a considerar a alteridade como faltante, evidenciando suas transformações subjetivas em suas recusas a deixar as sessões, acompanhadas por choros copiosos. Concomitante a isso, as mães passam a realizar deslocamentos importantes. Cátia, mãe de Igor, nas sessões que a incluíam, espelhava a psicóloga, imitando seus movimentos e, a posteriori, em um movimento criativo, acompanhava e conduzia o brincar do filho, demonstrando a elaboração da sua posição materna. No decorrer do processo, evidencia-se maior sintonia com Igor, reconhecendo em seus gestos e até mesmo nas manifestações somáticas, respostas singulares, o que antes Ihe era difícil. Isis, mãe de Serafim, é muito dedicada aos cuidados com o filho, inclusive, em demasia. Mostrava-se resistente em entrar em contato com os próprios afetos, impedindo-se, muitas vezes, de falar sobre as dificuldades. Ao longo dos atendimentos, passou a abrir-se, apresentando-se como uma mãe também faltante, isto é, que se permite sentir e ser frágil. Em termos winnicottinianos, permitiu-se ser a mãe que também falta. Para o autor, a mãe suficientemente boa é aquela que, em uma complexa sintonia, sustenta a subjetivação do seu bebê.

\section{Conclusões}

Conclui-se que as intervenções, orientadas pela psicanálise, puderam remontar cenários primordiais aos sujeitos que dela usufruíram, possibilitando que tanto os pacientes pudessem ocupar um lugar simbólico de fala e enunciação, como os próprios cuidadores pudessem, ainda que os atendimentos não fossem a eles dirigidos, (re)construir suas condições maternantes. Neste sentido, o trabalho institucional possibilitou um duplo resgate. Concedeu ao sujeito que não pôde gozar da função materna, a experiência de falasser (Lacan, 1988) e àquele que a havia perdido no limbo da solidão, a possibilidade de resgatá-la.

\section{Agradecimentos}

À FAPESP, financiadora da presente pesquisa (Auxílio à Pesquisa e Bolsa de Iniciação Científica).

Lacan, J. (1988). O seminário. Livro 11. In Os quatro conceitos da psicanálise. Rio de Janeiro: Jorge Zahar.

Winnicott, D. W. O brincar e a realidade. Rio de Janeiro: Imago editora LTDA, 1975 